
Kemp can't say much more about the skeletons because he had to flee the site in January, putting his team on flights out of the country and walling up his storehouses as a present-day revolution sent the country into chaos (see 'Archaeology in turmoil'). Although the situation soon calmed - in fact, Amarna did not suffer a single episode of looting Kemp has spent months waiting for permission to resume excavations. Other teams working in the country tell a similar story. "We've lost a year," says Frank Rühli, a palaeopathologist from the Centre for Evolutionary Medicine at the University of Zurich, Switzerland, who was scheduled to start work in February on human remains at the pyramids of Saqqara, near Cairo, and in the Valley of the Kings near Luxor.

The block on excavations has been the latest in a series of obstacles for archaeologists working in Egypt — the home of perhaps one-third of the world's antiquities, which reveal a vanished culture in unmatched detail (see 'New research in an ancient land').

Egyptian officials have said that their reluctance to allow work to restart stems from security concerns; they are now starting to grant permits for excavations. But a broader problem is that Egypt's Supreme Council of Antiquities (SCA), which coordinates all conservation and excavation activities in the country, has been mostly paralysed since the departure of its charismatic but controversial leader, Zahi Hawass. An ally of Egypt's deposed president, Hosni Mubarak, Hawass was forced to leave office in July. Since then, the agency has gained and lost three heads in quick succession, with the latest secretary-general, Mustafa Amin, appointed at the start of October.

The uncertainty dashed hopes of a swift return to normality for archaeological research, and unrest this week adds new concerns. "Everything is up in the air," said Kim Duistermaat, director of the Netherlands-Flemish Institute in Cairo, last month. As Egypt struggles to determine its future without Mubarak, archaeologists are wondering what their field might look like without Hawass.

\section{RISE OF THE PHARAOH}

The antiquities service was set up in 1858 to stem a different kind of chaos: the loss of artefacts. Early Egyptologists were little more than treasure hunters, who carted off everything from jewellery to entire monuments. Now, the SCA conducts its own excavations and approves and supervises foreign archaeological missions, as well as conserving and managing the country's wealth of antiquities and archaeological sites.

The service was initially led by French scholars, and did not have an Egyptian head until the 1950s. After becoming secretary-general of the SCA in 2002, Hawass catapulted what had been a fairly anonymous position into the limelight. He mixed with celebrities from Diana, Princess of Wales, to US President Barack Obama; fronted big-budget television documentaries; and even starred in his own reality show, Chasing Mummies. The image of Hawass enthusiastically unearthing treasures in his Indiana Jones-style hat became a familiar sight, and it gave Egyptology its first Egyptian face.

Even as he raised his own profile, Hawass did the same for archaeology in Egypt. His efforts attracted tourists and raised millions of dollars from international touring exhibitions of Tutankhamun's treasures. $\mathrm{He}$ fought hard - some felt too hard — for repatriation of artefacts, and pushed for Egyptian teams to conduct high-profile science (see Nature 472, 404-406; 2011). He raised money for state-of-the-art facilities in Egypt, notably persuading National Geographic in Washington DC to donate a US\$3-million scanner to the SCA in return for filming a project to scan Tutankhamun and other royal mummies; US broadcaster the Discovery Channel built two ancient-DNA labs in Cairo and donated \$250,000 towards testing the mummies' DNA. Hawass also tackled corruption and supported projects to develop archaeological sites, including building a suite of museums and dealing with rising groundwater that is threatening to damage sites across the country, including Giza's famous pyramids.

But critics claim that Hawass had a darker side: that as the years went on, he exerted excessive

\section{$\rightarrow$ NATURE.COM For more on Egyptian archaeology, visit: go.nature.com/jachks}

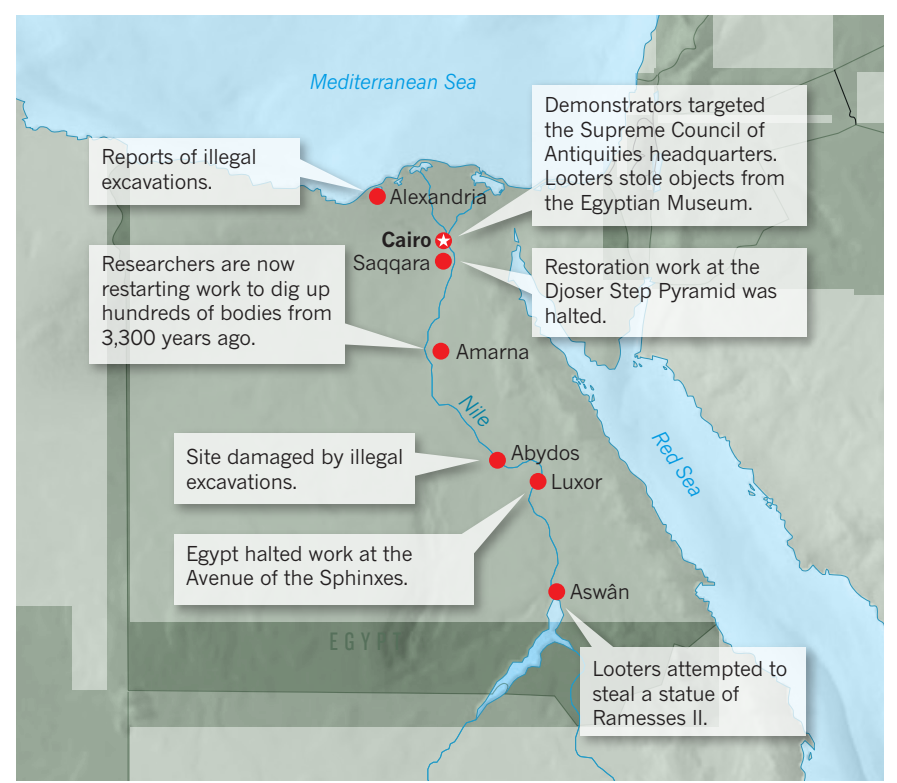

\section{Archaeology in turmoil}

Researchers in Egypt are trying to resume work at excavations that were shut down during the revolution in January. Looting and illegal building have plagued many important sites.

control and sought mainly to boost his own fame at the expense of other researchers and of high-quality science. Under Hawass, they complain, archaeologists were prevented from announcing their own discoveries. "This focus on him was something that really bothered people," says Duistermaat. "Even for foreign missions, you had to wait, even for weeks, until Zahi would come down and 'excavate' it."

Many archaeologists working in Egypt are reluctant to speak about Hawass on the record out of fear that he could regain influence in the country. But in private, several researchers say that Hawass was intolerant of opposition and blocked excavation permits to those who published results or theories that clashed with his own. Megan Rowland of the University of Cambridge, who has just completed a master's of philosophy degree on the political significance of Egypt's antiquities during the revolution, says that researchers who crossed Hawass became targets of intense criticism or had their permits revoked.

"Egyptological research is subject to very heavy censorship," she argues. In media interviews over the years, Hawass has accused several well known archaeologists of smuggling, scientific fraud or other improprieties. One researcher targeted by Hawass was Joann Fletcher, an Egyptologist from the University of York, UK. In a 2003 television documentary she suggested that a particular mummy was Queen Nefertiti, wife of Akhenaten - a finding that Hawass says he did not vet, and which was at odds with his own ideas.

Hawass told the Australian television programme 60 Minutes, "It is clear [Fletcher] made all this up because she wants to be famous." Fletcher was temporarily blocked from excavating in Egypt. She challenges Hawass's account and maintains that she did not break any rules.

Researchers also face restrictions when they seek to analyse artefacts. Despite Hawass's efforts, Egypt still has only limited capacity for sophisticated testing, such as carbon-14 dating and DNA analysis. But it is illegal to remove any archaeological artefact - even mud or pollen samples - from the country for analysis. Although some see this as an understandable response to the history of artefacts being illicitly exported, others complain that it is devastating for archaeological science. "This is what makes us look like fools at international conferences," says one researcher, based in Cairo, who does not wish to be named.

Just a year ago, it seemed impossible to imagine any change in this situation. The position of SCA secretary-general has traditionally been temporary, held for just two to three years. But Hawass had the support 

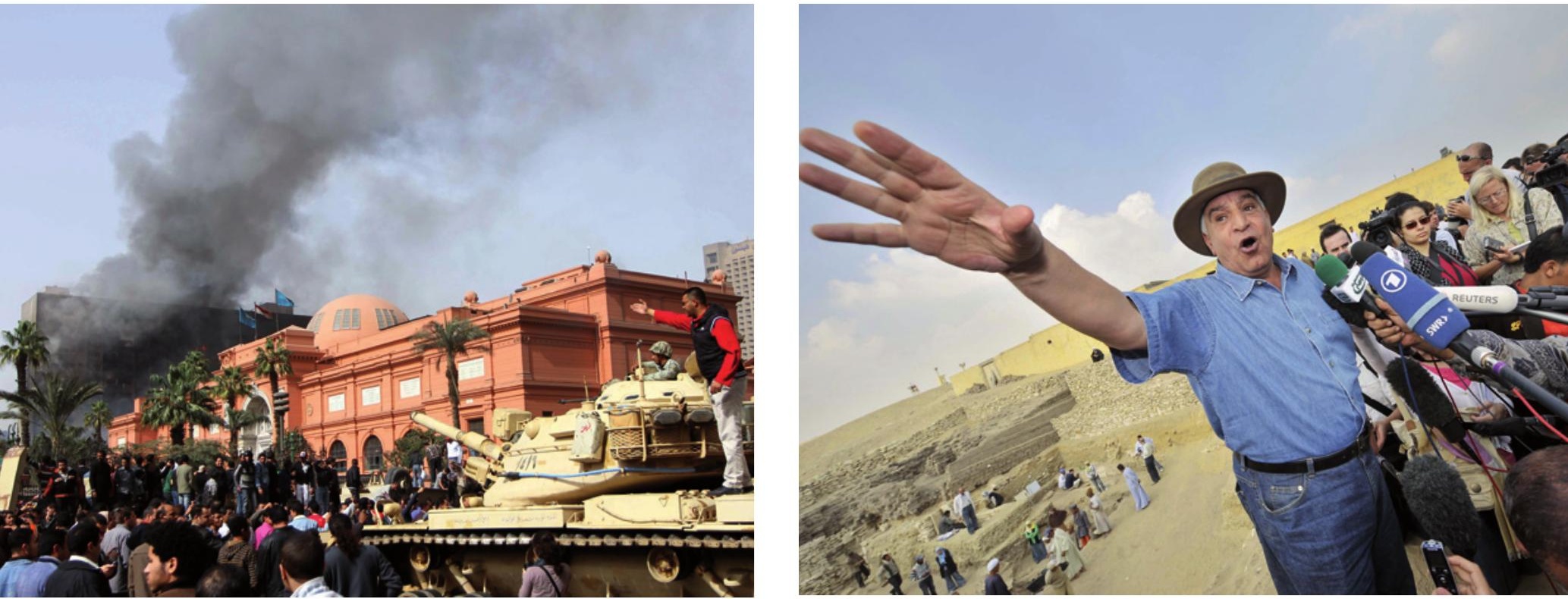

Protesters filled Tahrir Square in Cairo, near the Egyptian Museum (left), during the revolution, and the antiquities council lost its leader, Zahi Hawass (right).

of Mubarak, who extended his appointment.

The revolution changed all that. Hawass's hold on power started to slip when he denied, incorrectly, that any objects were missing after Cairo's Egyptian Museum was looted on 28 January. It was further eroded when he underestimated the extent of looting at important sites, despite reports that it was severe, and repeatedly voiced support for Mubarak. When Mubarak fell, Hawass's days were numbered. After resigning and being reappointed in March, Hawass finally left office in July.

He has barely appeared in public since, and has been under investigation by the Office of the Attorney General for a range of alleged offenses including stealing artefacts and diverting money from a touring Tutankhamun exhibition to a private charity owned by Mubarak's wife, Suzanne. "It's laughable," says Salima Ikram, an Egyptologist at the American University in Cairo, who has worked in Egypt for 18 years. "Zahi would never steal antiquities."

Today, Egypt's most famous archaeologist can be found tucked away on the ninth floor of a faded apartment block in the Mohandessin district of Cairo. Forbidden to leave Egypt while the investigation is ongoing, Hawass spends his days writing books in this modest office, surrounded by trophies, medals and photos of himself with celebrities. When Nature visits, he is charming and full of energy, bouncing up from his desk every few minutes to locate objects that will illustrate a point: his sweat-stained hat; his handwritten manuscripts; and a tall pile of stuffed envelopes that he says will prove his innocence in the attorney-general's investigation.

Hawass denies having close ties to Mubarak and calls the charges against him "ridiculous and untrue". Almost all of them have been dismissed, and the rest will soon be resolved, he says. Regarding his leadership style and appearances on television, Hawass says that it was important for him to maintain a high profile "to Egyptianize Egyptian antiquities". He denies taking credit for others' discoveries, arguing that he was required to scrutinize all results before they were announced to the media, to prevent unscrupulous archaeologists from making false claims. "Many people announce wrong information to get money," he says. He acknowledges that people have been banned from working in Egypt, but says that such decisions were made by a 60-person committee of the SCA and the sanctions were imposed only when researchers did not have proper credentials or broke SCA rules, such as announcing findings without approval.

Rather than harming Egyptian science, Hawass says that he raised standards, cleaned up corruption and trained a new generation of researchers. Hawass sees his work - and his ability to extract money from foreign television companies - as a high-profile success for Egyptian Egyptology. "I'm very proud of the results," he says, describing the paper reporting DNA analysis of Tutankhamun (Z. Hawass et al. J. Am. Med. Assoc. 303, 638-647; 2010) as "an incredible article". Highprofile projects like that, he says, help to "raise the global interest in Egyptology".

But foreign researchers have criticized the studies, complaining that raw data were not shared, making it impossible for them to assess the quality of - let alone repeat - the work. Some complain that the research was carried out purely for television audiences, whereas less glamorous projects might have had greater scientific value.

\section{BACK TO BUSINESS}

Love him or hate him, Hawass's departure has unnerved Egyptologists. Asked what they're hoping for from his successor, many researchers say that they want more open discussion of ideas, more sharing of data and collaborations between Egyptian and foreign teams.

But first, the SCA needs to get back on its feet. Researchers had hoped to resume work as soon as the security situation calmed. But the

\section{In October, the antiquities agency's headquarters was a hive of inactivity.} agency has been dogged by protests since the revolution, and Hawass's departure left it in chaos. None of his successors at the SCA has yet managed to last more than two months, and researchers say that progress has stalled.

"This is the first time in the course of five administrators I've lived through as an adult Egyptologist that it can't function," Ikram said last month. As researchers waited through the summer, permits were left unsigned and decisions unmade. When Nature visited in October, the agency's headquarters in Zamalek, Cairo, was a hive of inactivity, with dozens of men milling around its halls and the waiting room filled with bored employees watching the clock until it was time to go home. "We've been sitting here for six months," said one, clearly frustrated.

Everyone now hopes that Amin, the SCA's latest secretary-general, can get things started again. He holds a $\mathrm{PhD}$ in Islamic antiquities, and was previously head of the SCA's Islamic and Coptic department. Researchers say it is too early to comment on his leadership style, but because he does not specialize in Egyptology, it seems unlikely that he will share Hawass's one-man approach - or front documentaries about the pharaohs.

"He'll need people beside him," says Atef Abu El-Dahab, the affable head of the SCA's Egyptian antiquities sector. "First of all, me." 


\section{BURIED TREASURE New research in an ancient land}

Despite problems that have plagued Egyptology in recent years, the country continues to attract foreign researchers because of its special attributes. "Egypt is one of the few countries that maintained its borders and culture for 3,000 years," says Salima Ikram, an Egyptologist at the American University in Cairo. "It's unique in its historic and cultural span."

Key research areas include the origins of the country's civilization, how Egyptian society stayed stable for so long and the influence of climate change. Chris Naunton, director of the Egypt Exploration Society (EES) in London, says that rather than studying "old fashioned" tombs and temples, the EES is increasingly interested in "settlement archaeology" and how people used the land. One project, led by David Jeffreys, an archaeologist at University College London, is looking at how the path of the Nile river has shifted over time.

Techniques such as DNA analysis are encouraging archaeologists to focus on human remains, which can provide information about everything from hairstyles to the evolution of disease. Ikram is collaborating with David Lambert, a biologist at Griffith University in Brisbane, Australia, to extract DNA from mummies of ibises sacred birds in ancient Egypt - to study rates of mutation over time.

The country has a wealth of texts that can be cross-referenced with archaeological finds, and a dry climate that beautifully preserves organic materials. André Veldmeijer, assistant director of the NetherlandsFlemish Institute in Cairo, is studying leather trappings from a chariot, rediscovered last year in the Egyptian Museum in Cairo (right). The find includes harnesses, gauntlets and a bow case, complete with wear marks and an elaborate redand-green design, still bright after 3,000 years. J.M.

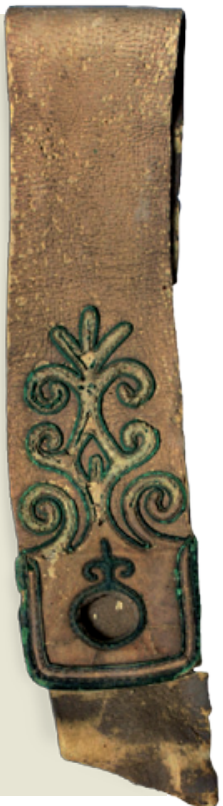

Amin has some huge problems to address before even thinking about boosting the quality of research. His first priority is the security of Egypt's sites and museums. Some looting is still going on, and the full extent of the losses isn't known, says Tarek El Awady, director of the Egyptian Museum in Cairo. "We're still waiting for the inventories," he notes. But the most serious challenge is illegal building, with locals trying to claim archaeological land at several sites.

El Awady says the underlying issue is that local people don't appreciate the importance of the country's archaeological heritage. Rowland blames this alienation on the Mubarak regime's "highly politicized approach to heritage management". She argues that Hawass had absolute power and focused on foreign audiences, which left local people with no sense of ownership of their own antiquities.

But El Awady defends his former boss. "He played an important role in increasing people's knowledge of Egyptian heritage," he says. Still, he adds, the looting shows the importance of "building bridges between museums, sites and local communities".

\section{LOST MILLIONS}

The second major problem facing Amin is funding. The SCA had a healthy income during Hawass's tenure, but the coffers are now empty, despite the extra millions of dollars that should have come in from the travelling exhibitions. "We have no money," confirms El-Dahab. He says that all conservation and excavation projects have been halted, and the agency is now borrowing millions of dollars from banks and the government just to pay salaries.

There is no shortage of conspiracy theories as to what might have happened to the cash, but El-Dahab says that it has gone to the many projects that Hawass championed, including the construction of 22 local museums, conservation and restoration work at important sites, and his efforts to deal with rising groundwater.

Hawass denies any impropriety and defends his record. "I spent 1 billion Egyptian pounds [US\$167 million] a year" in support of Egyptian archaeology, he says proudly. He adds that he had planned to bring in more funds through tourism and travelling exhibitions, and blames the political situation - which has drastically cut the number of foreign visitors - for the SCA's financial crisis.

To make matters worse, many of the agency's employees have been angrily protesting since the revolution for better pay and conditions, blockading SCA buildings and obstructing tourists. The agency has a huge staff - a spokesperson refused to even guess how many, but Egyptologists estimate that there are perhaps 40,000 permanent employees and another 15,000 or so on temporary contracts. But the SCA doesn't have the money to pay them, or enough work for them all to do. El Awady says that a large proportion of SCA staff should be let go: "We don't need all these workers."

However, it seems certain that there will not be large numbers of layoffs. The protesters forced out Amin's three predecessors, and Amin will need to keep employees on his side. He is now negotiating with the government for the funds to provide them all with permanent contracts. Amin also announced in October that he will carry out a comprehensive inventory of all SCA-owned land, selling or leasing any areas declared free of monuments and artefacts in order to raise money.

He promises to revive restoration work at the pyramid of Djoser, Egypt's oldest surviving stone building, and other major projects if the government gives him the money. Meanwhile, permissions for foreign research are starting to come through. Kemp's group finally returned to the field earlier this month.

Ultimately, however, the future of archaeology in Egypt depends not just on Amin, but on the outcome of Egypt's first democratic elections in decades, scheduled to begin on 28 November. Researchers are wondering whether the new political regime will take a nationalistic approach that favours Egyptian researchers, or become more open to foreign researchers and international collaborations.

And there is one more move that the new government could make. Egypt is reliant on funds from the millions of tourists who come to see its antiquities each year, and although visitor numbers have picked up slightly since the revolution, they are still low. El-Dahab says that the number of tourists visiting the country in September 2011 was only one-quarter of what would normally be expected.

If there was one thing that Hawass was good at, it was bringing in tourists, keen to visit after watching his exploits on television, or marvelling at Tutankhamun's travelling treasures. So it is not inconceivable that a new leader might yet invite the charismatic archaeologist back to the SCA.

Hawass has previously denied any interest in returning to his old job, but now seems to be repositioning himself. "I'm sorry to say it, but I'm the only one who can bring the tourists back," he told Nature. So would he offer his services, if asked? "I will never come back unless there is a stable government," he says. If the upcoming elections can deliver that, the man in the hat might yet rise again. $\quad$ SEE EDITORIAL P.445

Jo Marchant is author of Decoding the Heavens: Solving the Mystery of the World's First Computer (William Heinemann, 2008). 